\title{
Seasonal temperatures for the past $\sim 400$ years reconstructed from diatom and chironomid assemblages in a high-altitude lake (Lej da la Tscheppa, Switzerland)
}

\author{
Lucien von Gunten • Oliver Heiri · Christian Bigler • \\ Jacqueline van Leeuwen · Carlo Casty • \\ André F. Lotter · Michael Sturm
}

Received: 2 August 2006/ Accepted: 10 March 2007/Published online: 12 April 2007

(C) Springer Science+Business Media B.V. 2007

\begin{abstract}
We analysed a $42 \mathrm{~cm}$ long sediment record from Lej da la Tscheppa, a high-altitude lake (2,616 $\mathrm{m}$ a.s.l.) in the Upper Engadine valley (Switzerland) for subfossil diatoms, chironomids and pollen. The chronology of the top $21 \mathrm{~cm}$ of the record was established using ${ }^{210} \mathrm{~Pb}$ analysis using a constant-rate-of-supply model, and validated with ${ }^{137} \mathrm{Cs}$ measurements and the content of spheroidal carbonaceous particles. A tentative chronology for the lower part of the core was obtained through extrapolation of the sedimentation rates in the uppermost part of the record. Pollen assemblages in the record reflect regional changes in forestation and land-use patterns in the Upper Engadine valley and show no evidence
\end{abstract}

L. von Gunten $(\bowtie)$

Institute of Geography, University of Bern,

Hallerstrasse 12, 3012 Bern, Switzerland

e-mail: lucien.vongunten@giub.unibe.ch

O. Heiri · A. F. Lotter

Palaeoecology, Institute of Environmental Biology, Laboratory of Palaeobotany and Palynology, Utrecht University, Budapestlaan 4, 3584 CD Utrecht, The Netherlands

C. Bigler

NCCR Climate, University of Bern, Bern 3012,

Switzerland

C. Bigler

Ecology and Environmental Science,

Umeå University, KBC plan 5, Umea 901 87, Sweden of significant local human activity in the lake's catchment. Diatom assemblages record a distinct increase in planktonic taxa since the early 19th century, suggesting a decrease in the duration of ice-cover. In contrast, chironomid assemblages remained stable during a large part of the record. We applied an established chironomid-based July air temperature transfer function and a newly developed diatom-based spring air temperature transfer function to reconstruct past seasonal air temperature changes at Lej da la Tscheppa. The reconstructions indicate a diatom-inferred warming trend in spring temperatures during the past ca. 400 years, whereas chironomid-inferred summer temperatures suggest a slight cooling trend.

L. von Gunten · J. van Leeuwen

Institute of Plant Sciences, University of Bern,

Altenbergrain 21, Bern 3013, Switzerland

C. Casty

Climate and Environmental Physics, University of Bern, Sidlerstrasse 5, Bern 3012, Switzerland

M. Sturm

Department of Surface Waters (SURF), Swiss

Federal Institute for Environmental Science and Technology (EAWAG), Dubendorf 8600, Switzerland 
These biota-based reconstructions are in good agreement with the centennial-scale temperature trend in an independent reconstruction of regional temperatures in the Upper Engadine region based on instrumental records and documentary proxy evidence from the Alps. Our results suggest that, in high-altitude lakes, independent chironomid- and diatom-based seasonal temperature reconstruction is possible and can be successfully used to track seasonal temperature trends.

Keywords Alpine lake - Diatoms - Chironomids · Pollen · Ice-cover $\cdot$ Seasonal temperature reconstructions

\section{Introduction}

Lake sediments are amongst the few natural archives for studying past environmental changes available at high altitudes (Battarbee et al. 2002; Lotter et al. 2002; Lotter and Birks 2003). The remains of a number of aquatic organisms such as diatoms, chironomids, chrysophytes, cladocerans, or ostracods preserve well in lake sediments and reflect past changes in assemblage composition. Past changes in aquatic ecosystems can provide important information about climatic variability, especially for organism-groups which show a strong present-day relationship to climatic parameters such as temperature (e.g. Lotter et al. 1999; Heiri and Lotter 2005; Kamenik and Schmidt 2005; Barley et al. 2006; Woodward and Shulmeister 2006). Quantitative temperature reconstructions based on the distribution of aquatic organisms in modern calibration sets (e.g. Lotter et al. 1997; Brooks and Birks 2000; Bigler and Hall 2002) are now available from a range of regions. They have been used to provide estimates of temperature change associated with major climatic shifts at the end of the last iceage (e.g. Brooks and Birks 2000; Lotter et al. 2000; Heiri and Millet 2005), with abrupt climatic fluctuations during the early and mid-Holocene (e.g. Heiri et al. 2004b; Schmidt et al. 2004a), and with the long-term trends in Holocene climate (e.g. Bigler et al. 2002; Larocque and Hall 2004).

An evaluation of such palaeoclimate reconstructions by comparison with instrumental measurements is in many cases hampered by the widespread pollution of lake ecosystems during the industrial period, and by other human activities such as catchment clear-cutting and pasturing (e.g. Wick et al. 2003). Local human activity can lead to distinct and abrupt changes in lake ecosystems and to artefacts in quantitative climate reconstructions based on subfossil aquatic organisms. As a consequence, such climate reconstructions are often considered unreliable if evidence for past local human activity is encountered (e.g. Heiri and Lotter 2003; Heiri et al. 2003a). In contrast to European lowland lakes, human influence on high-altitude lakes is less severe (Müller et al. 1998). Hence, such mountain lakes provide the opportunity to compare past temperature variability during the critical time-window of the past ca. 500 years with independent highquality temperature reconstructions based on instrumental records and historical evidence. In addition, alpine lakes react sensitively to climatic changes, because the amplitude of temperature changes at high elevation sites is even more pronounced than on a global scale (Beniston et al. 1997). This makes high-altitude lacustrine sediments ideal archives for environmental reconstructions, providing the possibility of comparing palaeoclimate reconstructions during the past centuries with instrumental measurements or historical records.

The aim of this study is to reconstruct the environmental conditions of the past ca. 400 years at a high-altitude lake situated above treeline (Lej da la Tscheppa, $46^{\circ} 27^{\prime} \mathrm{N}, 9^{\circ} 45^{\prime} \mathrm{E}, 2,616 \mathrm{~m}$ a.s.l.). Specifically, we explore whether diatoms and chironomids in such high-altitude lakes can provide temperature reconstructions using quantitative inference models and whether these reconstructions are in agreement with recently developed palaeotemperature reconstructions based on observational data for this part of the Alps (Casty et al. 2005). Since human activity has proven to be one of the major complicating factors in the application of temperature transfer functions (Heiri and Lotter 2005), the study is supplemented by high-resolution pollen analysis in order to detect changes in the catchment vegetation related to anthropogenic activity. Our study site is located well above the treeline 
in the Upper Engadine region and is at present largely unaffected by direct human impact.

A large number of palaeoenvironmental reconstructions are available from the Upper Engadine region, including vegetation history (e.g. Zoller and Brombacher 1984; Gobet et al. 2003, 2004), sedimentology (Leemann and Niessen 1994, Ohlendorf 1998), glaciology (e.g. Maisch et al. 2000), geomorphology (e.g. Castelli 2000; Koch 2003), and climatology (e.g. Gensler 1978). The palaeolimnological studies from this region mainly concentrated on human-induced eutrophication (Züllig 1982; Ariztegui and Dobson 1996; Lotter 2001) and the relationship between climate and sedimentation processes (Ohlendorf et al. 1997). However, these studies were carried out in the large lakes of the main valley of the Upper Engadine at lower elevations, while the study of the multitude of high-altitude lakes in the region has only started recently.

\section{Study area and site}

Lej da la Tscheppa $\left(46^{\circ} 27^{\prime} \mathrm{N}, 9^{\circ} 45^{\prime} \mathrm{E}\right)$ is a small lake located at $2616 \mathrm{~m}$ a.s.l. in a steep southeast facing slope north of Sils-Maria, Upper Engadine, Switzerland (Fig. 1). It has a surface area of 7.96 ha, with a length of $400 \mathrm{~m}$, a width of $290 \mathrm{~m}$, and a shore length of $1.15 \mathrm{~km}$ (Marrer 1975; Klucker 1992). The lake was formed in a dead-ice hole and reaches a maximal depth of $32 \mathrm{~m}$ (Margreth 2006). The lake has a small outflow to the south and at present it is mainly fed through surface inflow (Klucker 1992).

The catchment (102 ha surface) consists mainly of green granites (Castelli 2000). Calcareous Mesozoic sediment intrusions are possible (Maisch et al. 1999) and may explain the circumneutral lake-water $\mathrm{pH}$ (Table 1). The lake is dammed by a series of terminal moraines from the Pontresina stadium (local equivalent to the Egesen stadium, or Younger Dryas) of the Crasta-Tscheppa Glacier. Until recently, a small remnant of the glacier was situated ca. $700 \mathrm{~m}$ upslope of the lake. An intact rock glacier still reaches down to ca. $100 \mathrm{~m}$ from the lake shore (Koch 2003).

As consequence of its altitude, restricted accessibility, and a catchment consisting of a large proportion of bare rock, the land-use possibilities in the area of Lej da la Tscheppa are limited. The steep trail up to the lake is usually only used by hikers or fishermen. Fish have been introduced in Lej da la Tscheppa at least since 1970 . However, as there is evidence for fish release in other high-Alpine lakes since the end of the 15th century (Pechlaner 1966, 1984), an earlier stocking of the Lej da la Tscheppa with fish can not be excluded.

Due to its location in the Central Alps, the Upper Engadine is characterised by a continental, summer-dry climate including strong daily and seasonal temperature fluctuations (Gensler 1978) and relatively little precipitation (985 mm year ${ }^{-1}$, mean 1864-2004, Sils-Maria) (Begert et al. 2005). Due to its high elevation, the meteorological conditions prevailing at Lej da la Tscheppa are extremely harsh. Mean temperatures lie below $0^{\circ} \mathrm{C}$ for about 6 months and snow and ice covers the lake for a large part of the year (Swiss Federal Institute for Snow and Avalanche Research 2004). These conditions lead to an average ice-cover duration from November to June (Klucker 1992).

The most abundant forest tree in the Upper Engadine is larch (Larix decidua). Together with Swiss stone pine (Pinus cembra) it forms a conifer forest, which is typical for the Central Alps (Ellenberg 1996). The present timber line in the
Fig. 1 Location (A) and setting (B) of the studied lake (Lej da la Tscheppa), including main towns SilsMaria (1) and St. Moritz (2)

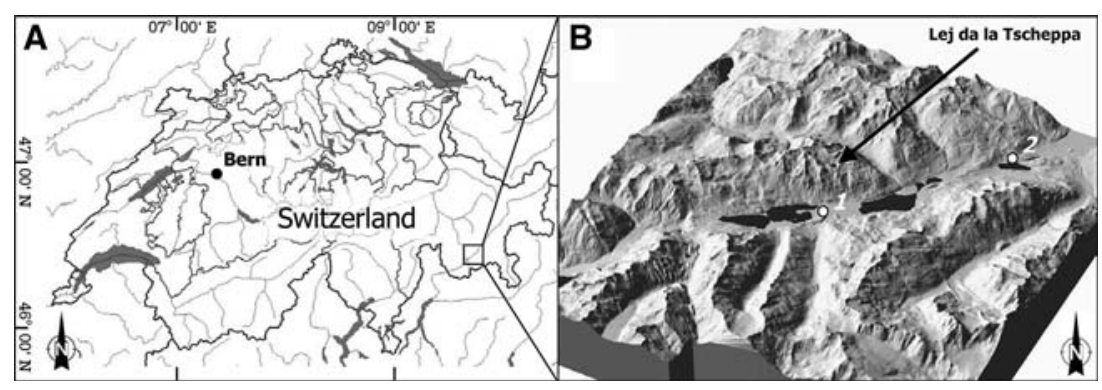


Table 1 Major environmental variables of Lej da la Tscheppa according to Marrer (1975) $)^{\mathrm{a}}$, Klucker (1992) ${ }^{\mathrm{b}}$, and Bigler et al. $(2006)^{\mathrm{c}}$

\begin{tabular}{|c|c|c|c|c|c|}
\hline & & $29.08 .1975^{\mathrm{a}}$ & $12.08 .1992^{\mathrm{b}}$ & $08.08 .2002^{\mathrm{c}}$ & 10.07 .2004 \\
\hline Air temp $\left({ }^{\circ} \mathrm{C}\right)$ & & 9.30 & - & 5.73 & - \\
\hline \multirow[t]{2}{*}{ Water temp $\left({ }^{\circ} \mathrm{C}\right)$} & Epilimnion & 7.2 & - & 10.2 & 7.1 \\
\hline & Hypolimnion & - & - & 6.6 & - \\
\hline Secchi depth (m) & & - & 17.5 & 11.0 & - \\
\hline \multirow[t]{2}{*}{ Conductivity $(\mu \mathrm{S} / \mathrm{cm})$} & Epilimnion & 31.2 & - & 35 & 38 \\
\hline & Hypolimnion & - & - & 40 & - \\
\hline \multirow[t]{2}{*}{$\mathrm{DOC}(\mathrm{mg} \mathrm{C} / \mathrm{l})$} & Epilimnion & - & - & 0.7 & - \\
\hline & Hypolimnion & - & & 0.9 & - \\
\hline $\mathrm{pH}$ & Epilimnion & 7.65 & 7.0 & 6.9 & 6.9 \\
\hline \multirow[t]{2}{*}{ Alkalinity (mmol/l) } & Epilimnion & 0.43 & 0.40 & 0.44 & - \\
\hline & Hypolimnion & & - & 0.46 & - \\
\hline LOI $\left(550^{\circ} \mathrm{C}\right)(\%)$ & & - & - & 8 & - \\
\hline \multirow[t]{2}{*}{ Total-nitrate (mg N/l) } & Epilimnion & & - & $<0.5$ & - \\
\hline & Hypolimnion & - & - & $<0.5$ & - \\
\hline \multirow[t]{2}{*}{ Total-phosphate ( $\mu \mathrm{g} \mathrm{P} / \mathrm{l})$} & Epilimnion & - & - & 7.6 & - \\
\hline & Hypolimnion & - & - & 11.1 & - \\
\hline \multirow{2}{*}{ Silica $\left(\mathrm{mg} \mathrm{H}_{3} \mathrm{SiO}_{4} / \mathrm{l}\right)$} & Epilimnion & - & - & 9.2 & - \\
\hline & Hypolimnion & - & - & 9.5 & - \\
\hline
\end{tabular}

Upper Engadine lies between 2,100 $\mathrm{m}$ a.s.l. and 2,250 $\mathrm{m}$ a.s.l. (Gobet et al. 2003), well below Lej da la Tscheppa. The sparse vegetation surrounding the lake mainly belongs to the Salicetum herbaceae plant community that is typical for high-elevation silicate sites with short vegetation period (Reisigl and Keller 1987; Grabherr and Mucina 1993).

Until the end of the 19th century, the Upper Engadine was only sparsely populated $(3,000$ inhabitants in 1850). But from the 1870 s onwards the expansion of summer and winter tourism triggered a rapid economical and demographic growth (Rüdishühli 2001). Today, about 17,000 inhabitants live in the Upper Engadine and during the tourist season this number can reach up to 100,000 .

\section{Materials and methods}

In August 2002 a short core was taken in $25 \mathrm{~m}$ depth using a UWITEC gravity corer. The $41.6 \mathrm{~cm}$ long sediment core was mainly composed of silt and silty gyttja. ${ }^{210} \mathrm{~Pb}$ and ${ }^{137} \mathrm{Cs}$ were analysed by gamma spectrometry following the methods outlined by Appleby et al. (1986).

The core was sampled at $0.5 \mathrm{~cm}$ intervals. Samples $\left(0.5 \mathrm{~cm}^{3}\right.$ wet sediment $)$ for diatom analyses were treated with standard procedures (Battarbee 1986), using $\mathrm{HCl}$ and $\mathrm{H}_{2} \mathrm{O}_{2}$, and repeated washing in distilled water. Slides were prepared using Naphrax ${ }^{\odot}$. To estimate the valve concentration (valves $\mathrm{cm}^{-3}$ ), microspheres were added to the samples (Battarbee and Kneen 1982). Enumeration of diatoms was done using a Leica DMR microscope at 1000× magnification with phase contrast optics. Diatom taxonomy largely followed Krammer and Lange-Bertalot (1986-1999). With the exception of two samples with very low diatom concentrations, a minimum of 400 valves was counted in each sample.

Samples for chironomid analysis were immersed in $5 \% \mathrm{KOH}$ solution for $2 \mathrm{~h}$ and then washed through a $100 \mu \mathrm{m}$ sieve. Chironomid remains were hand-picked under a stereomicroscope (40× magnification) and mounted on microscope slides in Euparal ${ }^{\odot}$. Chironomids were identified under a microscope at 400x magnification, mainly based on Wiederholm (1983), Schmid (1993), Rieradevall and Brooks (2001), Heiri et al. (2004a) and Brooks et al. (2007).

Calibration datasets for the development of diatom- and chironomid-based inference models were based on the analysis of surface sediments from 64 and 114 lakes for diatoms and chironomids, respectively (for more details about calibration datasets see Lotter et al. 1997, 1998; Heiri 
and Lotter 2005; Bigler et al. 2006). Transfer functions for calculating temperature estimates were based on Weighted Averaging-Partial Least Squares regression (WA-PLS; ter Braak and Juggins 1993; ter Braak et al. 1993) and squareroot transformed percentage data, and were calculated using the program $\mathrm{C} 2$ version 1.4 (Juggins 2003).

For pollen analysis one $\mathrm{cm}^{3}$ of wet sediment was used and Lycopodium tablets (Stockmarr 1971) were added for estimation of pollen concentration (pollen $\mathrm{cm}^{-3}$ ). The standard chemical procedure included treatment with $\mathrm{HCl}, \mathrm{KOH}$, HF, acetolysis, staining with Fuchsine and mounting in glycerol. Pollen grains were identified under a light microscope at $400 \times$ magnification, using the reference collection of the Institute of Plant Sciences, University of Bern, and standard determination keys (Punt and Clarke 1984; Moore et al. 1991; Punt et al. 1995). Spheroidal Carbonaceous Particles (SCP) were counted on the pollen slides. Minimal pollen sums were 500 per sample. All percentages of pollen, spores, algae, and SCP's were calculated on the basis of a pollen sum that includes tree, shrub and herb pollen, but excludes pollen of aquatic plants.

Casty et al. (2005) reconstructed seasonal (monthly) Alpine temperatures and precipitation on a $0.5^{\circ}$ by $0.5^{\circ}$ grid $(\sim 60 \times 60 \mathrm{~km})$ back to $\mathrm{AD}$ 1500 (and $\mathrm{AD} 1659$, respectively), using a large number of temperature station data all over Europe (and indices derived from documentary evidence for the pre-instrumental period prior to $A D$ 1659). The reconstruction is based on a principal component (PCA) regression approach, where the predictand is the Alpine grid and the predictors are the station or index data (for details see Casty et al. 2005; data are available at the NOAA WDC homepage, http://www. ncdc.noaa.gov/paleo/pubs/casty2005/casty2005. $\mathrm{html}$ ). For comparison with our biotic records, we selected the grid point at $46.25^{\circ} \mathrm{N}$ and $9.25^{\circ} \mathrm{E}$ $\left( \pm 0.5^{\circ}\right)$ that best represents the location of Lej da la Tscheppa. However, temperatures in this dataset are not corrected for the altitude of Lej da la Tscheppa but represent an estimate for the grid cell. Therefore, we compare only temperature trends and not the absolute temperature values with our reconstructed temperatures from
Lej da al Tscheppa. The monthly temperature data back to AD 1659 are seasonally averaged (e.g. winter is the mean of December, January, February and so forth).

\section{Results}

Dating

Dating of the Lej da la Tscheppa sediments was based on ${ }^{210} \mathrm{~Pb},{ }^{137} \mathrm{Cs}$ and the abundance of SCP's. Based on the ${ }^{210} \mathrm{~Pb}$ measurements, we calculated an age-depth relationship for the uppermost $21 \mathrm{~cm}$ of the gravity core using the Constant Rate of Supply (CRS) model (Binford 1990) (Fig. 2). This age-depth relationship was validated by using the ${ }^{137} \mathrm{Cs}$ measurements and the SCP curve (Appleby 1998, 2001; Rose 2001). The SCP-peak at $3.75 \mathrm{~cm}$ depth, which in Switzerland corresponds to the maximal fuel consumption peak in AD 1973 (Swiss Federal Office of Energy 2004) fits the lead-based CRS-model very well and confirms the ${ }^{210} \mathrm{~Pb}$-based age-depth curve. The ${ }^{137} \mathrm{Cs}$ curve, however, does not show two clearly distinguishable peaks for the fallout maxima from the nuclear weapon testing (AD 1963) and from the Chernobyl incident (AD 1986). Therefore the ${ }^{137} \mathrm{Cs}$ results have not further been used for dating. In the absence of other chronological information we extrapolated the average sedimentation rate of the top $21 \mathrm{~cm}$ of the gravity core beyond the range of ${ }^{210} \mathrm{~Pb}$ dating to provide a coarse age approximation for the sediments down to $41 \mathrm{~cm}$ depth.

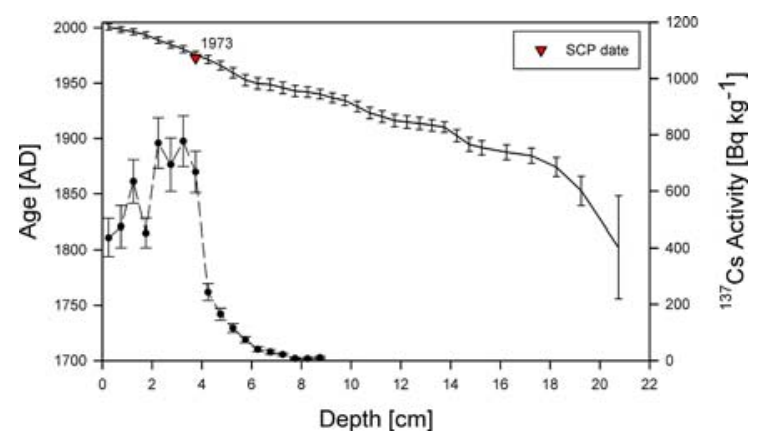

Fig. $2{ }^{210} \mathrm{~Pb}$ depth-age model (solid line) and measured values of ${ }^{137} \mathrm{Cs}$ (dashed line) 
Diatoms

Fragilaria and Cyclotella species dominate the diatom assemblages from Lej da la Tscheppa, which is typical for circumneutral Alpine lakes (e.g. Lotter et al. 2002; Bigler et al. 2006). The main feature in the diatom stratigraphy is a gradual shift from a periphytic and Fragilaria dominated phase to assemblages dominated by Cyclotella comensis (Fig. 3). In the lower part of the sediment core (ca. $23-41 \mathrm{~cm}$ ) the diatom assemblage is dominated by Fragilaria brevistriata and Pinnularia microstauron var. microstauron. However, other periphytic taxa such as Navicula pupula var. pupula, Amphora inariensis or Denticula tenuis are also important. Subsequently, both Cyclotella radiosa and Denticula tenuis reach high relative abundances and dominate the diatom assemblage between $21 \mathrm{~cm}$ and $23 \mathrm{~cm}$. The remaining part of the diatom stratigraphy (above $21 \mathrm{~cm}$ ) is largely dominated by Cyclotella comensis, reaching relative abundances of $30-65 \%$. The total diatom concentration is very low between ca. 6 and $30 \mathrm{~cm}$ sediment depth.

\section{Chironomids}

Chironomid assemblages in Lej da la Tscheppa (Fig. 4) are dominated by taxa typical for Alpine lakes such as Micropsectra radialis-type, Procladius, Paracladius, Pseudodiamesa, Zavrelimyia type A and Paratanytarsus austriacus-type (e.g. Bretschko 1974; Guilizzoni et al. 1996; Heiri 2001; Heiri and Lotter 2003; Heiri and Millet 2005). A total of 30 pupal thoracic horns with a low length to width ratio indicate that the Procladius specimens found in the sediment core probably belong to 'Procladius tatrensis' as described in Gowin and Zavrel (1944) (Heiri et al. 2003b). The diversity of chironomid assemblages was very low as is typical for alpine lakes. Chironomid assemblages in the lowest $25 \mathrm{~cm}$ of the core were dominated by Micropsectra radialis-type and Procladius. At ca. $14 \mathrm{~cm}$ depth the abundance of a number of chironomid taxa including Zavrelimyia A, Paratanytarsus austriacus-type, Heterotrissocladius and Pseudodiamesa increases, whereas the percentages of Micropsectra radialistype decrease. At $7 \mathrm{~cm}$ depth a second prominent shift in chironomid assemblage composition is registered, with a distinct increase in Pseudodiamesa and the disappearance of Procladius. The top two samples are characterised by a reduction of Pseudodiamesa and a distinct increase in Paracladius. Total chironomid concentrations are highest in the bottom part of the core, showing distinct increases at 14 and $25 \mathrm{~cm}$ depth.

Pollen

The lowest part of the sediment core (below $29 \mathrm{~cm}$ depth) is characterised by a relatively high

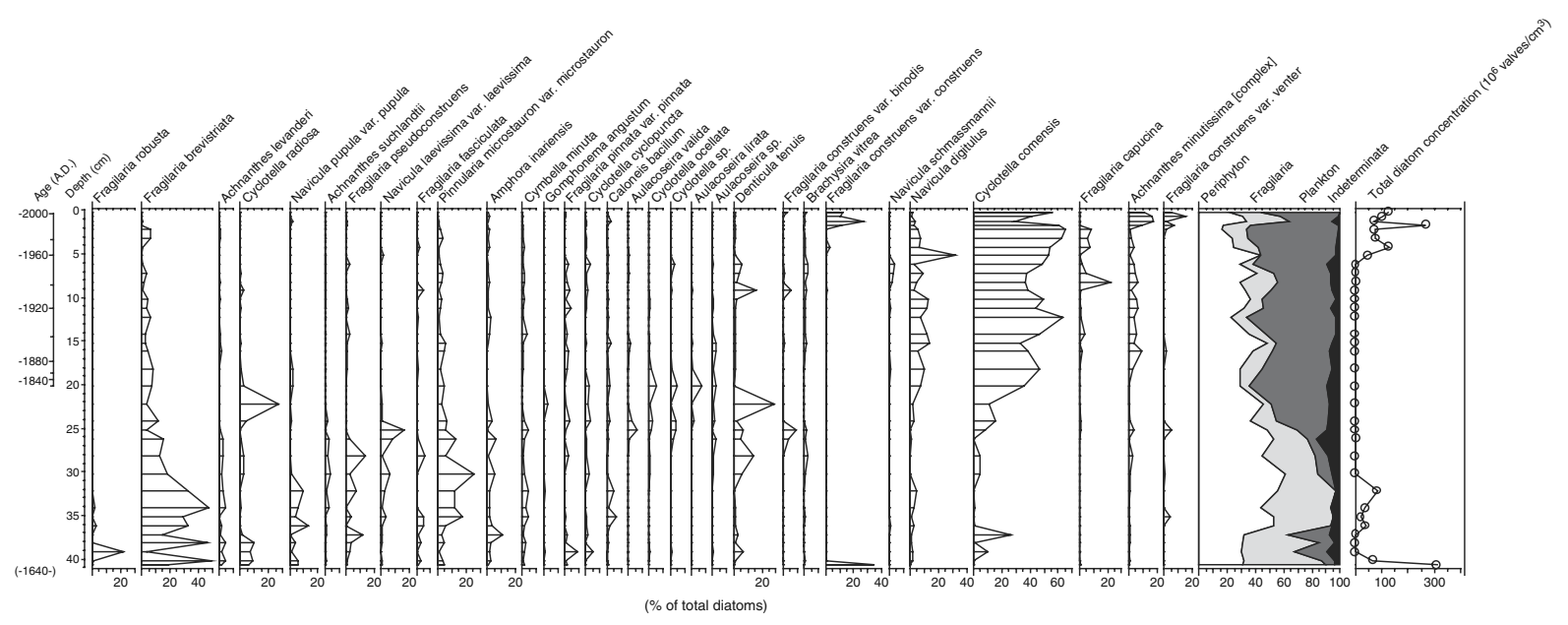

Fig. 3 Biostratigraphical record of selected diatom taxa 


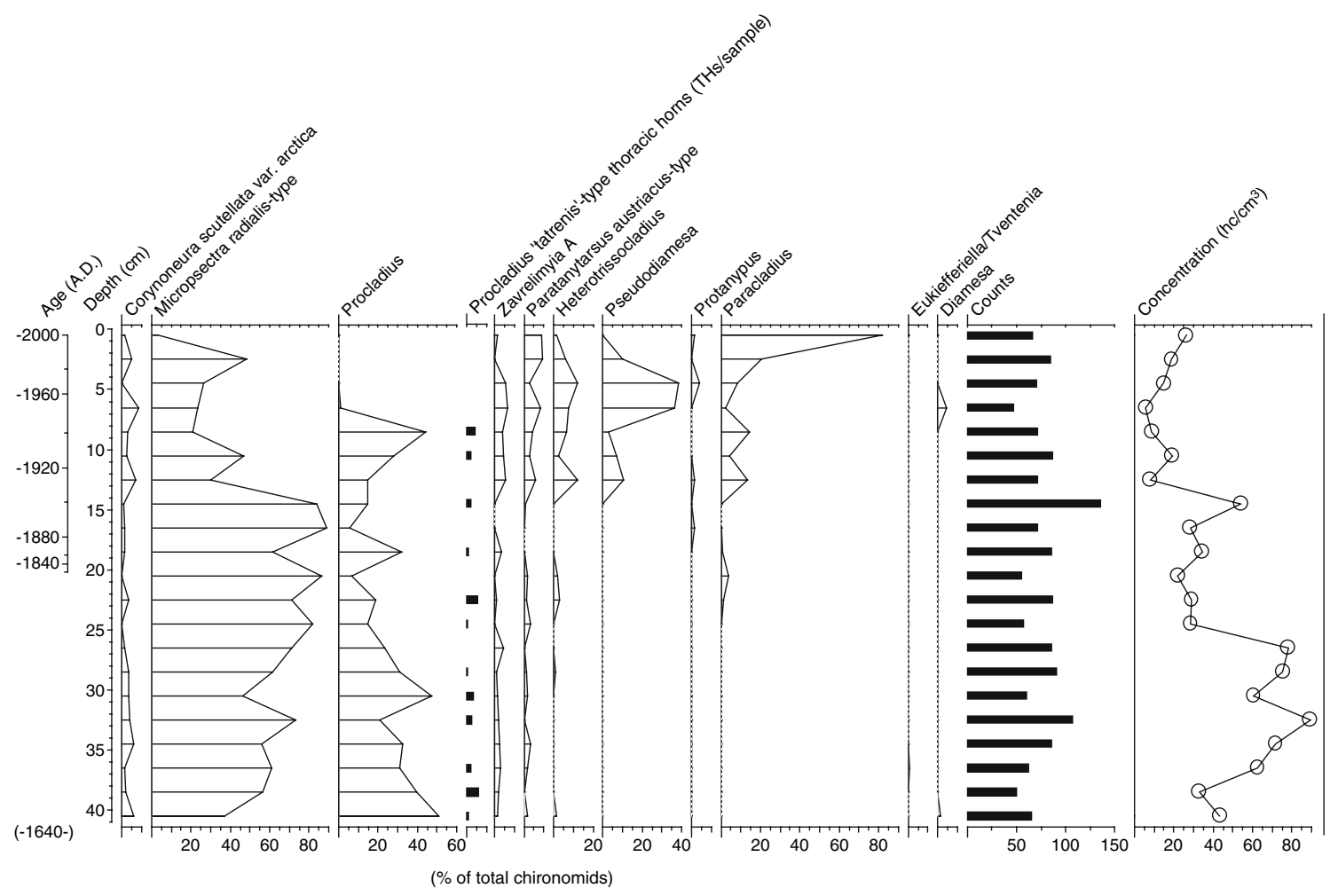

Fig. 4 Biostratigraphical record of selected chironomid taxa. Chironomid remains are indicated as percentages of the total number of chironomid head capsules except where indicated otherwise

percentage of tree $(>40 \%)$ and shrub $(>30 \%)$ pollen (Fig. 5). Picea and Pinus cembra type are the most abundant tree pollen, whereas shrub pollen is originating mainly from Alnus viridis and Juniperus. Subsequently, the tree and shrub pollen decrease gradually and are partly replaced by herb pollen (mainly Poaceae). This trend is reversed in the uppermost part of the core (above $10 \mathrm{~cm}$ ) when tree and shrub pollen increase again. The total pollen concentrations are low throughout the core but increase below ca. $25 \mathrm{~cm}$ depth.

Temperature reconstructions based on diatoms and chironomids

The use of diatoms as quantitative indicators for temperature in other seasons than summer has been examined in recent studies (e.g. Schmidt et al. 2004b). In high latitude lakes, Sorvari et al. (2002) report a high correlation of the compositional structure of diatom assemblages to spring temperatures. They suggest that this correlation is mainly due to changes in the duration of the lake ice-cover, as spring temperature is determining to onset of ice break-up and length of snow cover in high latitude regions. They therefore propose that spring temperature reconstructions reflect the ecology of remote high-latitude lakes better than summer temperature reconstructions. Similarly, in their study of a high-alpine lake Lotter and Bigler (2000) showed that spring temperature explained the highest amount of variance in the diatom data, which they likewise attributed to the duration of lake ice-cover. The ice cover duration in the Engadine is strongly related to regional spring air temperatures (Livingstone 1997). Based on these studies, we use a diatom-spring temperature transfer function for reconstructing past temperatures from diatom assemblages at Lej da la Tscheppa rather than a diatom summer temperature transfer function as has been applied in lakes in subarctic regions and in the subalpine 


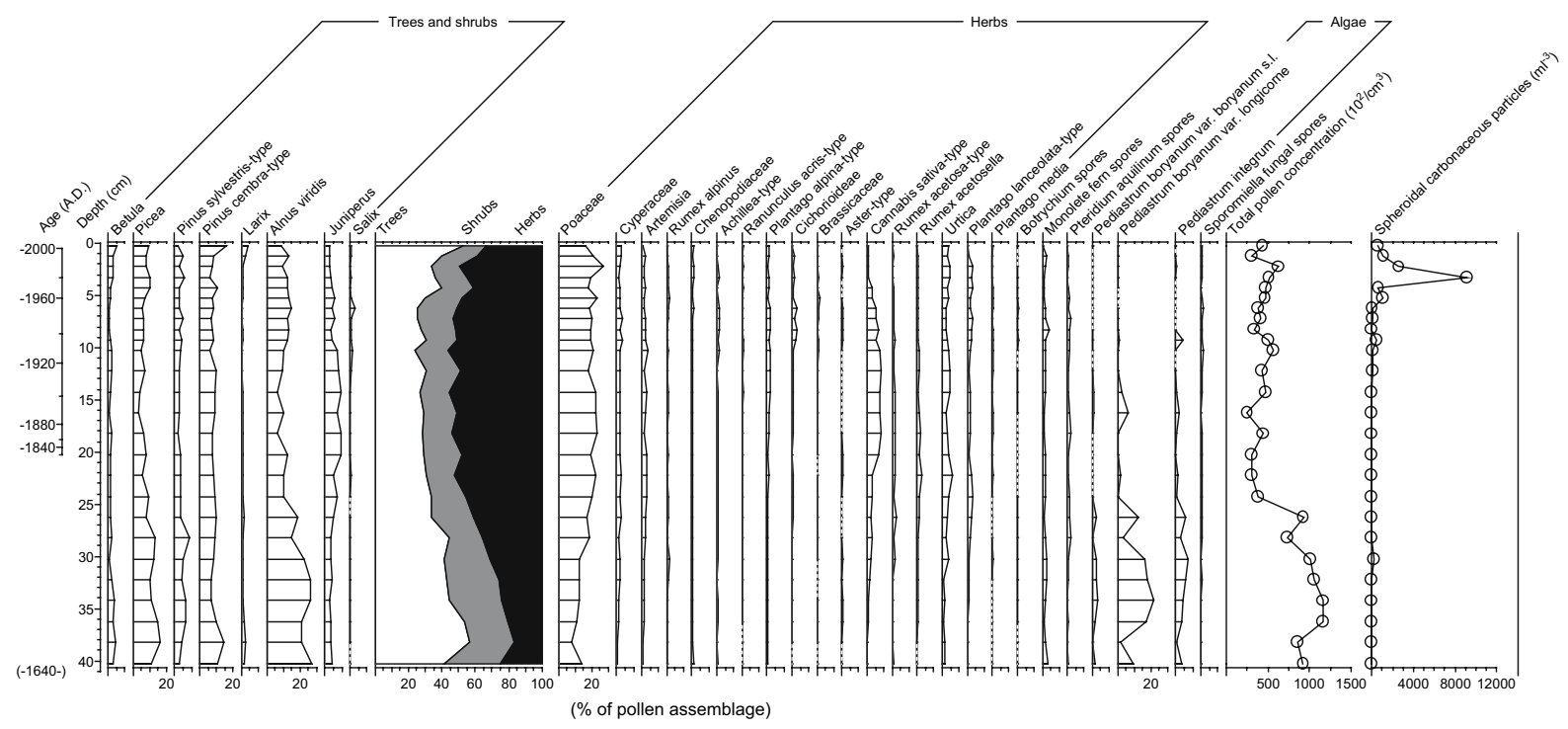

Fig. 5 Biostratigraphical record of selected pollen taxa

elevation belt (e.g. Lotter et al. 1997; Bigler and Hall 2002).

The diatom-inferred spring temperature reconstruction implemented in this study is based on a calibration dataset collected from 68 lakes in Switzerland, France and northern Italy (Lotter et al. 1997). After deletion of four outliers according to Lotter et al. (1997), the final dataset included 64 sites, covering a spring temperature gradient ranging from $-1.7^{\circ} \mathrm{C}$ to $10.7^{\circ} \mathrm{C}$. A spring temperature inference model based on two-component Weighted Averaging-Partial Least Squares (WA-PLS) regression and calibration was developed. The prediction ability of the developed transfer function yielded a coefficient of determination based on leave-one-out crossvalidation $\left(r^{2}\right)$ of 0.81 and a root mean square error of prediction (RMSEP) of $1.59^{\circ} \mathrm{C}$ (Table 2 ). All 52 diatom taxa recorded in the sediment core of Lej da la Tscheppa were represented in the calibration set.

The diatom-inferred spring temperature reconstruction shows lowest temperature values (around $0^{\circ} \mathrm{C}$ ) in the lowest part of the sediment core (Fig. 8). Throughout the 18th century, an increase in spring temperature is inferred, reaching a temperature value of $4^{\circ} \mathrm{C}$ at the beginning of the 19th century. Subsequently, temperatures fluctuate between $1^{\circ} \mathrm{C}$ and $4^{\circ} \mathrm{C}$, including some cooler and warmer episodes during the 20th century.

For the chironomid-based temperature reconstruction a calibration set consisting of chironomid assemblages from surface sediments of 114 lakes and corresponding July air temperature estimates was available (Heiri and Lotter 2005; Bigler et al. 2006). Based on these data, an initial chironomid-temperature inference model using two-component WA-PLS regression was developed and screened for outliers. Potential outliers were identified as samples with a high prediction residual. These samples were deleted if they were either (1) associated with unusual hydrological conditions (e.g. regular flooding by nearby rivers or water diversion) (eight lakes), (2) distinctly deeper and with a larger lake area and catchment than most other calibration set lakes (two lakes with maximum lake depth 36-85 $\mathrm{m}$; 52-76 ha lake area), (3) strongly influenced by running water chironomid taxa (two lakes), or (4) showed high negative prediction residuals and were strongly affected by shading through high cliffs at the southern side of the lake catchment (three lakes). After outlier deletion, taxa with less than three occurrences were removed from the data set. The final, screened calibration set consisted of 
Table 2 Description of the calibration sets (after removal of outliers) and performance of inference models $\left(r^{2}=\right.$ coefficient of determination, RMSE $=$ root mean square error, RMSEP = root mean square error of prediction)

\begin{tabular}{|c|c|c|}
\hline & Diatoms & Chironomids \\
\hline \multicolumn{3}{|l|}{ Calibration set } \\
\hline Number of samples & 64 & 99 \\
\hline Environmental variable & Spring T & July T \\
\hline $\operatorname{Min}\left({ }^{\circ} \mathrm{C}\right)$ & -1.9 & 5.0 \\
\hline Mean $\left({ }^{\circ} \mathrm{C}\right)$ & 5.0 & 12.2 \\
\hline Median $\left({ }^{\circ} \mathrm{C}\right)$ & 5.8 & 11.9 \\
\hline $\operatorname{Max}\left({ }^{\circ} \mathrm{C}\right)$ & 10.7 & 18.4 \\
\hline \multicolumn{3}{|l|}{ Inference model } \\
\hline Model type & WA-PLS & WA-PLS \\
\hline Number of components & 2 & 2 \\
\hline$r^{2}$ (apparent) & 0.96 & 0.93 \\
\hline RMSE (apparent) $\left({ }^{\circ} \mathrm{C}\right)$ & 0.69 & 1.08 \\
\hline$r^{2}$ (jackknifed) & 0.81 & 0.89 \\
\hline RMSEP (jackknifed) $\left({ }^{\circ} \mathrm{C}\right)$ & 1.59 & 1.36 \\
\hline Mean bias (jackknifed) $\left({ }^{\circ} \mathrm{C}\right)$ & 0.00 & -0.07 \\
\hline Max bias (jackknifed) $\left({ }^{\circ} \mathrm{C}\right)$ & 1.49 & 1.30 \\
\hline
\end{tabular}

chironomid assemblages from 99 lakes ranging from mean July air temperatures of $5-18.4^{\circ} \mathrm{C}$ and with a maximum lake depth of 2.2-49 m. This dataset contained 94 chironomid taxa and produced a two-component WA-PLS inference model with an $r^{2}$ of 0.89 and a RMSEP of $1.36^{\circ} \mathrm{C}$ (Table 2).

Chironomid taxa found in Lej da la Tscheppa were all present in the chironomid-temperature transfer-function. However, considerable doubt exists whether the present-day abundances of Procladius head capsules in the calibration set assemblages provide a reasonable approximation for the distribution of $P$. tatrensis-type in the Alps (see Discussion). We, therefore, decided to calculate chironomid-inferred July temperatures for both chironomid assemblages including and excluding Procladius for the Lej da la Tscheppa record (Fig. 7).

The chironomid-based temperature reconstruction based on the entire chironomid assemblages infers mean July air temperatures around $9.5^{\circ} \mathrm{C}$ in the lowest part of the sediment core. Temperatures show a decreasing trend during most of the record and inferred temperatures reach ca. $8.5^{\circ} \mathrm{C}$ at $8.5 \mathrm{~cm}$ sediment depth (ca. AD 1941). Between $8.5 \mathrm{~cm}$ and $6.5 \mathrm{~cm}$ depth
(AD 1941-1949), coeval with the disappearance of Procladius head capsules from the record, temperatures cool abruptly to ca. $7.3^{\circ} \mathrm{C}$. This cooling trend is continued in the uppermost part of the sediment record and mean July air temperatures of ca. $6.1^{\circ} \mathrm{C}$ are reconstructed in the topmost sample in the Lej da la Tscheppa record. If Procladius is excluded from the chironomid assemblages the transfer-function also reconstructs a decreasing temperature trend for the Lej da la Tscheppa record. However, the absolute decrease in inferred temperatures is considerably smaller with temperatures around $7.7^{\circ} \mathrm{C}$ at ca. $40 \mathrm{~cm}$ depth and temperatures of ca. $7.3^{\circ} \mathrm{C}$ at $6.5 \mathrm{~cm}$ depth (AD 1949; Fig. 7). In the uppermost sediment layers (<6.5 cm depth), where Procladius is absent, inferred temperatures using the two different approaches are identical.

\section{Discussion}

The fossil records

\section{Diatoms}

The main change in diatom composition consists of a shift from an assemblage dominated by periphytic species (mainly Fragilaria brevistriata) to a planktonic one (mainly Cyclotella comensis). In several studies in arctic and alpine lakes, a high proportion of periphyton to plankton has been reported as indicative for long ice-cover (Smol 1988; Douglas and Smol 1999; Lotter and Bigler 2000; Koinig et al. 2002; Karst-Riddoch et al. 2005). Winter and spring ice-cover is one of the most relevant factors in high-altitude lakes influencing the life-cycle of organisms (Gabathuler 1999), as it decouples the lake water from atmospheric processes and has a strong effect on the light regime (Gray and Male 1981). Changes in the ice-cover duration in other Upper Engadine lakes are mainly controlled by spring air temperatures (Livingstone 1997). In Lej da la Tscheppa, the shift from periphyton- to planktondominated assemblages would thus suggest a decrease in ice-cover length and an increase in spring air temperatures. 
The increase in planktonic diatoms takes place rather gradually between ca. $20 \mathrm{~cm}$ and $26 \mathrm{~cm}$ sediment depth. This suggests an increase in spring air temperatures between ca. AD 1750 and 1800. The strongest change in diatom assemblages takes place at the end of this transition with a strong increase in Cyclotella comensis, a diatom which only occurred in low abundances in Lej da la Tscheppa before AD 1750.

In arctic and alpine lakes, the in-lake productivity and nutrient concentrations tend to increase with rising water temperatures (e.g. Douglas and Smol 1999). Surprisingly, total diatom concentration in Lej da la Tscheppa shows a decreasing trend when temperatures are increasing, with the exception of the uppermost few centimetres. A possible explanation is that warmer temperatures may have caused melting of glaciers in the catchment of Lej da la Tscheppa, which increased erosional input and sedimentation rates, leading to a dilution of the diatom record. A concomitant decrease in the concentration of chironomid head-capsules and pollen supports the idea that there is a change in the sedimentation rate at a depth of ca. $25 \mathrm{~cm}$. However, while the diatom concentration increases again in the uppermost sediments, pollen and chironomid concentrations do not show a similar trend.

\section{Chironomids}

Interestingly, the major changes in the chironomid profile from Lej da la Tscheppa do not coincide with the shift to planktonic diatom assemblages. In the period before ca. AD 1920 chironomid assemblages are very stable in the sediment record. The first major shift in the chironomids takes place at ca. AD 1910. This is followed ca. 30 years later by the abrupt disappearance of Procladius from the lake and an increase in Pseudodiamesa, and in the most recent sediments by an increase in Paracladius. A strong relationship between chironomid assemblage composition and mean July air or water temperatures has been reported from a number of arctic, subarctic, and temperate regions (e.g. Lotter et al. 1997; Brooks and Birks 2001; Larocque et al. 2001; Porinchu et al. 2002). The relationship between temperature and the chironomid fauna in high-altitude lakes still remains to be studied in more detail. However, based on the present knowledge it seems probable that if the chironomid changes in the uppermost sediment layers are related to climatic change, they would reflect changes in absolute summer temperatures rather than shifts in spring temperatures and ice-cover duration as has been described for diatoms. One of the most conspicuous changes in the chironomid record is the disappearance of Procladius around AD 1950. The relative large and motile Procladius larvae have been reported to be a main food item for salmonids in a lake in the French Alps (Serra-Tosio 1978). In a highaltitude lake from the Northern Swiss Alps, the absence of Procladius head capsules in the youngest part of a 9,000 year chironomid record was explained as possibly being the consequence of fish introduction (Heiri and Lotter 2003). In Lej da la Tscheppa salmonids have been introduced at least since AD 1974. However, it is likely that the stocking of the lake with fish began significantly earlier. In other high-altitude lakes in Switzerland the earliest documented introduction of salmonids has been reported from ca. AD 1900 (Grimås and Nilsson 1962) although earlier undocumented introductions are possible in the Alpine region (Pechlaner 1966, 1984). Abrupt decreases in Procladius have also been reported as a consequence of reduced oxygen availability to benthic organisms in a stratified lake (Heiri and Lotter 2003). However, in this study decreases in Procladius were accompanied by abrupt reductions in the overall concentration of chironomid remains and by lower abundances of other profundal-inhabiting chironomid taxa. In Lej da la Tscheppa, chironomid concentrations stay stable in the upper $\sim 10 \mathrm{~cm}$ of the record and the disappearance of Procladius is not associated with major changes in other chironomids. Hence, the most likely explanation for the disappearance of Procladius from the record at ca. 1950 AD seems the introduction of fish into the lake.

Fossil thoracic horns in the record and originating from Procladius pupal exuviae indicate that the Procladius head capsules found in Lej da la Tscheppa belong to Procladius 'tatrensis' as described in Gowin and Zavrel (1944) (Fig. 4). This Procladius species has rarely been reported 
in modern material. The specimens described by Gowin and Zavrel (1944) were collected in 1933 and 1939 in the high Tatra Mountains (former Czechoslovakia) and a pupa with an almost identical thoracic horn has been collected in 1934 in East Greenland by Andersen (1937). In the Alps thoracic horns of Procladius tatrensistype have been found in a number of fossil records (see Heiri et al. 2003b). However, in surface sediment samples the species has not yet been reported from the region. In total 71 lake surface sediments from the Alps have been screened for Procladius pupal remains (O. Heiri, unpublished data). In these samples that cover the entire temperature gradient along which Procladius is present in the Swiss Alps, all 16 isolated Procladius thoracic horns did not belong to $P$. tatrensis-type. It therefore seems that this species is presently rare in Alpine lakes and that the distribution of Procladius in the available surface sediment dataset may not adequately reflect the ecology of Procladius 'tatrensis'-type in the Alps.

\section{Pollen}

The pollen record from Lej da la Tscheppa is strongly affected by long-distance pollen transport from vegetation occurring at lower altitudes (>300 $\mathrm{m}$ lower). The main change in the pollen record is a decrease of tree and shrub pollen in favour of non-arboreal pollen types (NAP). The majority of NAP pollen are cultural indicators (Cannabis sativa-type, Urtica, Plantago lanceolata-type, Rumex) or indicative of open landscapes (e.g. Poacea and Cyperaceae). Under natural, undisturbed conditions an increase in NAP pollen in Alpine pollen records is generally interpreted as a climate-related decrease in treeline altitude leading to a longer distance between the source of arboreal pollen and the study site (e.g. Heiri et al. 2004b; Tinner and Kaltenrieder 2005). However, the vegetation in the Upper Engadine has been strongly affected by local human activity since at least the Medieval times (Gobet et al. 2003). In such a cultural landscape an opening of the local vegetation can also be the consequence of shifts in anthropogenic land-use due to socio-economic reasons (e.g. Tinner et al. 2003).
The NAP curve shows a distinct increase in the lower part of the core that occurs at approximately the same time as the diatom-inferred spring air temperature increase at end of the 18th century (Fig. 6). However, the trend to more open landscapes in the NAP curve is already apparent before temperatures increase. Local human activity in the Alps can also be affected by a range of factors unrelated or indirectly related to climate and hence any straightforward relationship between the pollen assemblages and spring temperatures may have been masked. However, it is possible that increased spring temperatures at the end of the 18th century led to intensified pasturing in the Upper Engadine and, as a consequence, to the increase in the NAP curve.

The most recent increase in arboreal pollen (AP) is most likely related to modern reforestation policy and the reduction of pasturing in the region rather than to any climatic influence on regional land-use. While the regional pollen signal exhibits a distinct trend, the pollen types reflecting the local, high-altitude vegetation show comparatively few changes. The abundance of pollen types of several grazing indicators such as Poaceae, Urtica, Rumex and Plantago show an increase between ca. 5 and $30 \mathrm{~cm}$ sediment depth. However, this is most likely an effect of calculating percentage values and related to the lower input of AP during this period. Furthermore, none of these grazing indicators show percentage abundances of $>10 \%$ that have been reported for Alpine lakes with intense pasturing in the lake catchment (Hausmann et al. 2002; Wick et al. 2003). Hence the pollen record suggests that human activity in the catchment of Lej da la Tscheppa has remained low throughout the past $\sim 400$ years.

\section{Temperature reconstructions}

There is a distinct difference in the timing of assemblage changes in the diatom and the chironomid record. Assuming that diatoms of Lej da la Tscheppa are largely reflecting spring temperature changes and chironomids are mainly responding to summer temperature variability, this suggests that reconstructions of different 


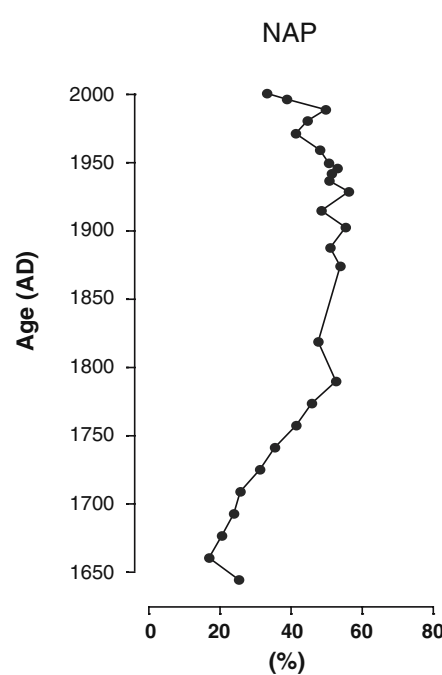

Fig. 6 Percentage curves of non-arboreal pollen (NAP) and planktonic diatoms, and relative spring air temperature reconstructed from observational and historical data

seasonal temperature trends may be inferred from the sediment sequence. If the diatominferred spring air temperatures are compared with the regional spring temperature reconstruction based on observational data (Casty et al. 2005), a similar trend is apparent between the two records (Fig. 8). In the reconstruction of Casty et al. (2005) there is a clear warming trend in spring temperatures at the end of the 18th century for the grid cell representing the area around Lej da la Tscheppa. Before ca. AD 1750 the reconstruction indicates relatively cool spring temperatures, whereas generally warmer temperatures are reconstructed after $1750 \mathrm{AD}$. Despite the uncertainties associated with the diatom-based reconstruction (e.g. relatively large model prediction errors, uncertain chronology and coarse sampling resolution) both diatom inferred values and the reconstruction based on observational data show similar trends. Both indicate that temperatures drop slightly in the late 19th and early 20th century, before a second phase of warmer temperatures is recorded around $\mathrm{AD}$ 1950. This second warm phase is longer in the diatom reconstruction, reaching from ca. AD 1920 to 1980 (Fig. 8). However, inferred mean spring air temperature using diatoms at Lej da la Tscheppa, especially the warming that starts at ca. AD 1750, show almost twice as large amplitudes
(Thin line: relative spring air temperature, bold line: LOESS smoothed; Cleveland and Devlin 1988; span 0.12) (Casty et al. 2005)

as the temperature trends in the observational data. The generally good agreement between the records supports our interpretation that changes in diatom assemblages in the lake were largely driven by changes in spring temperature and icecover duration, and indicate that, as previously suggested by Sorvari et al. (2002), calibration of diatom transfer-functions against spring temperature may be more appropriate in alpine and arctic environments than the calibration against summer temperature.

In contrast with both available spring temperature reconstructions, the centennial-scale trend in summer temperature as inferred by instrumental and observational data shows a slight decrease over the studied period (Casty et al. 2005). A decline in July air temperatures is also recorded in the chironomid-inferred temperatures (Figs. 7, 8 ), both in the reconstruction based on the full chironomid assemblages, and in the reconstruction in which Procladius head capsules have been excluded. The decreasing trend in the chironomid-based reconstruction using the entire assemblages is more pronounced and is strongly influenced by the disappearance of Procladius from the record at ca. $8 \mathrm{~cm}$ sediment depth (Fig. 7), which leads to a ca. $2.5^{\circ} \mathrm{C}$ decrease in inferred temperatures in the upper part of the record. A distinct decline in July temperatures is 


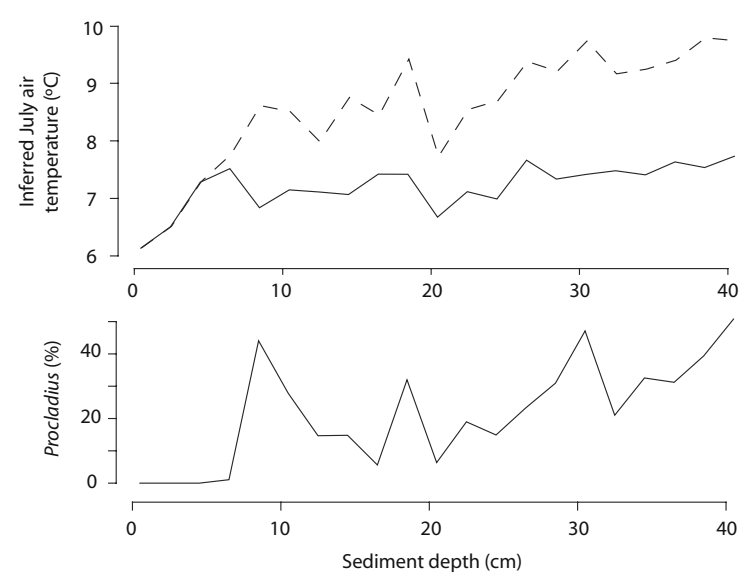

Fig. 7 Chironomid inferred mean July air temperatures for the Lej da la Tscheppa record if Procladius tatrensistype is treated as equivalent to Procladius in the chironomid temperature transfer function (upper panel, dashed line) and if Procladius is excluded from the reconstruction (upper panel, solid line). The lower panel indicates the percentage abundance of Procladius in the Lej da la Tscheppa record also apparent in the youngest part of the reconstruction in which Procladius has been excluded. However, temperatures only cool by ca. $1.5^{\circ} \mathrm{C}$, which seems a more realistic value, and the reconstruction agrees better with inferred temperatures for the Lej da la Tscheppa region based on instrumental and historical records (Fig. 8). The chironomid-based and the historical and instrumental reconstruction show a reasonably good agreement until ca. AD 1980. The most recent warming trend in the instrumental and historical reconstruction, however, is not recorded by the chironomids. The explanation for this discrepancy will have to remain speculative. However, possibly it is related to the disappearance of the small glacier in the lake catchment during the past decade, which may have affected the hydrology of the lake and possibly influenced the aquatic ecosystem, leading to the distinct changes in chironomid assemblages in the youngest part of the sediment record (Fig. 4).
Fig. 8 Diatom-inferred spring air temperatures and chironomid-inferred summer air temperatures from Lej da la Tscheppa compared with spring and summer air temperatures reconstructed from observational and historical data (Casty et al. 2005). The diatom and chironomid records are smoothed with a 3sample moving average and the Casty et al. (2005) reconstructions with a LOESS smoother (Cleveland and Devlin 1988; span 0.12). The values inferred by Casty et al. (2005) for the $0.5^{\circ}$ latitude/longitude grid cell best representing the geographical location of Lej da la Tscheppa are shown and, since they represent relative temperature changes, these records have been centered to $0^{\circ} \mathrm{C}$ mean

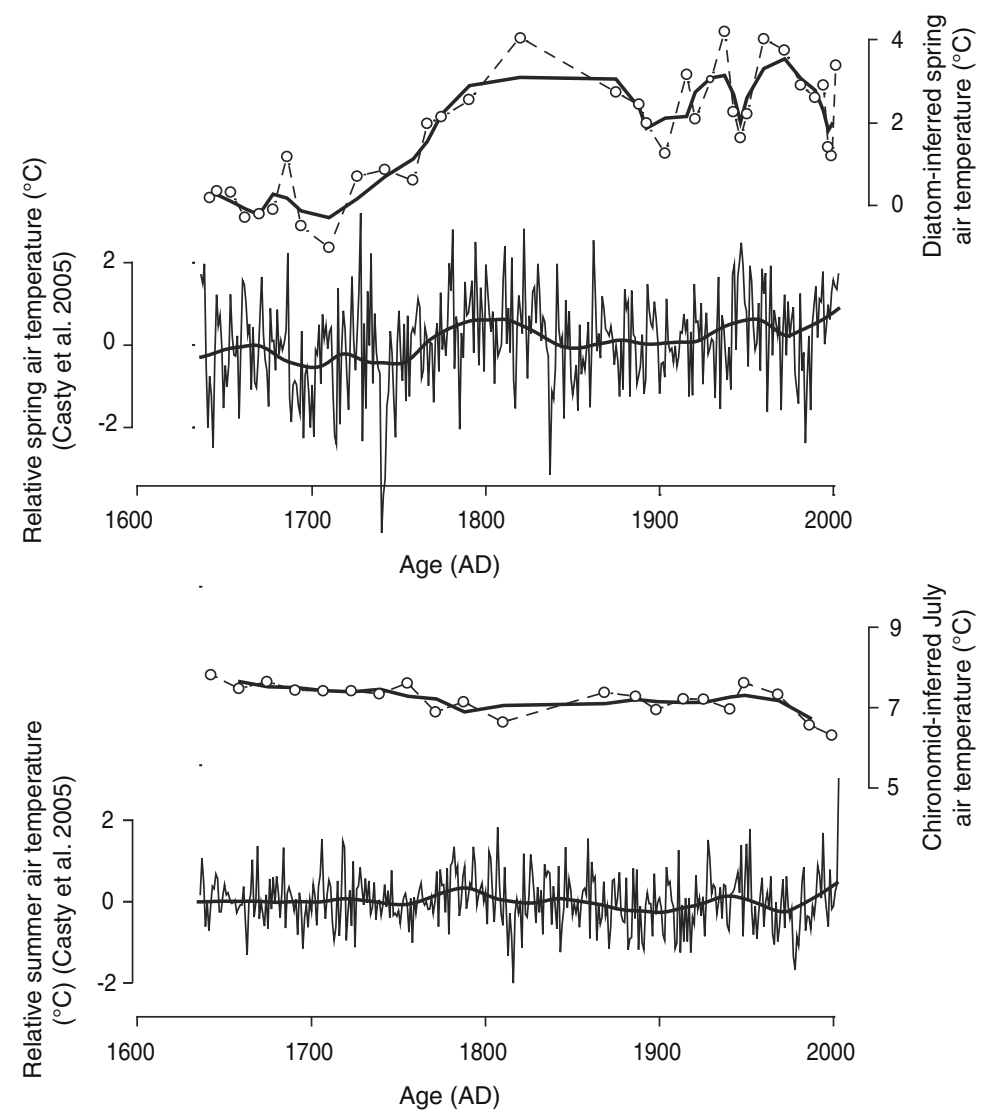




\section{Summary and conclusions}

A $42 \mathrm{~cm}$ sediment core from Lej da la Tscheppa, reflecting the past ca. 400 years of sedimentation, has been analysed for subfossil pollen, diatom and chironomid assemblages. The pollen record reflects regional changes in forest cover and landuse in the Upper Engadine valley and shows no evidence of significant local human activity at the lake. The diatom record is mainly influenced by a shift from benthic to planktonic diatom taxa, an ecological signal that in high-altitude lakes is generally interpreted as a decrease in the duration of winter and spring ice-cover. Interestingly, diatom and chironomid assemblages showed a different timing and pattern of assemblage changes which suggest that they reacted to different environmental signals. In the Upper Engadine area, lake ice-cover duration is strongly influenced by spring temperatures. We used a diatom-based spring air temperature transferfunction to reconstruct past spring temperatures at Lej da la Tscheppa, whereas chironomids were used to reconstruct past changes in July air temperature at the lake. Both reconstructions show a good agreement with the centennial to decadal scale trends in the available temperature reconstruction based on instrumental and historical records although in the case of the chironomids this is only true if Procladius is eliminated from the chironomid assemblages before the application of the transfer-function. The amplitude of temperature changes in the diatom- and chironomid-based temperature reconstructions was higher than in the reconstruction based on instrumental and historical records. At present the reasons for this discrepancy can not be resolved although possibly some of the local geographical differences in the synoptic temperature reconstruction by Casty et al (2005) are smoothed out in a $0.5^{\circ}$ by $0.5^{\circ}$ grid. Perhaps the most significant finding of our study is that chironomid and diatom assemblages in Lej da la Tscheppa are reacting to different seasonal components of past temperature change, with diatoms reflecting past ice-cover duration and chironomids temperatures during the open-water season. Although this still needs further confirmation, our results suggest that in high-altitude lakes, such as
Lej da la Tscheppa, largely independent reconstructions of seasonal temperature trends may be possible by combining chironomid and diatom analysis.

Acknowledgements We would like to thank B. Ammann, A. Blass, E. Gobet and W. Tinner for helpful advice and discussions during the preparation of this manuscript, and F. Oberli and F. Verbruggen for assistance in sample preparation. This project was supported by the Swiss National Science Foundation through the NCCR Climate program, by the SNF-project ENLARGE (grant no. 200021-103892/1) and by the Nederlandse Organisatie voor Wetenschappelijk Onderzoek (NWO)/Aard- en Levenswetenschappen (ALW) grant no. 813.02.006. This is Netherlands Research School of Sedimentary Geology (NSG) publication no. 2007.03.03. C. Casty was supported by the European Commission under the Fifth Framework Programme Contract Nr. EVR1-2002-000413, project PACLIVA.

\section{References}

Andersen FS (1937) Über die Metamorphose der Ceratopogoniden und Chironomiden Nordost-Grönlands. Medd Grønland 116:1-95

Appleby PG (1998) Dating recent sediments by ${ }^{210} \mathrm{~Pb}$ : problems and solutions. Proceeding of the 2nd NKS/ EKO-1 seminar, Helsinki, 2-4 April 1997. STUK, Helsinki, pp 7-24

Appleby PG (2001) Chronostratigraphic techniques in recent sediments. In: Last WM, Smol JP (eds) Basin analysis, coring, and chronological techniques. Kluwer Academic Publishers, Dordrecht, The Netherlands, pp 171-201

Appleby PG, Nolan PJ, Gifford DW, Godfrey MJ, Oldfield F, Anderson NJ, Battarbee RW (1986) Pb-210 dating by low background gamma-counting. Hydrobiologia 143:21-27

Ariztegui D, Dobson J (1996) Magnetic investigations of framboidal greigite formation: a record of anthropogenic environmental changes in eutrophic Lake St Moritz, Switzerland. Holocene 6:235-241

Barley EM, Walker IR, Kurek J, Cwynar LC, Mathewes RW, Gajewski K, Finney BP (2006) A northwest North American training set: distribution of freshwater midges in relation to air temperature and lake depth. J Paleolimnol 36:295-314

Battarbee RW (1986) Diatom analysis. In: Berglund BE (ed) Handbook of Holocene paleoecology and paleohydrology. John Wiley and Sons, Ltd., New York, pp 527-570

Battarbee RW, Kneen MJ (1982) The use of electronically counted microspheres in absolute diatom analysis. Limnol Oceanogr 27:184-188

Battarbee RW, Thompson R, Catalan J, Grytnes JA, Birks HJB (2002) Climate variability and ecosystem 
dynamics of remote alpine and arctic lakes: the MOLAR project. J Paleolimnol 28:1-6

Begert M, Schlegel T, Kirchhofer W (2005) Homogeneous temperature and precipitation series of Switzerland from 1864 to 2000. Int J Climatol 25:65-80

Beniston M, Diaz HF, Bradley RS (1997) Climatic change at high elevation sites: an overview. Clim Change 36:233-251

Bigler C, Hall RI (2002) Diatoms as indicators of climatic and limnological change in Swedish Lapland: a 100lake calibration set and its validation for paleoecological reconstructions. J Paleolimnol 27:97-115

Bigler C, Heiri O, Krskova R, Lotter AF, Sturm M (2006) Distribution of diatoms, chironomids and cladocera in surface sediments of thirty mountain lakes in southeastern Switzerland. Aquat Sci 68:154-171

Bigler C, Larocque I, Peglar SM, Birks HJB, Hall RI (2002) Quantitative multiproxy assessment of longterm patterns of Holocene environmental change from a small lake near Abisko, northern Sweden. Holocene 12:481-496

Binford MW (1990) Calculation and uncertainty analysis of ${ }^{210} \mathrm{~Pb}$ dates for PIRLA project lake sediment cores. J Paleolimnol 3:253-267

Bretschko G (1974) The chironomid fauna of a highmountain lake (Vorderer Finstertaler See, Tyrol, Austria, 2237 masl). Entomol Tidskr Suppl 95:22-33

Brooks SJ, Birks HJB (2000) Chironomid-inferred late-glacial and early-Holocene mean July air temperatures for Krakenes Lake, western Norway. J Paleolimnol 23:77-89

Brooks SJ, Birks HJB (2001) Chironomid-inferred air temperatures from Lateglacial and Holocene sites in north-west Europe: progress and problems. Quat Sci Rev 20:1723-1741

Brooks SJ, Langdon PG, Heiri O (2007) The identification and use of Palaearctic chironomids in palaeoecology. Quat Res Assoc Tech Guide 10 (in press)

Castelli S (2000) Geomorphologische Kartierung im Gebiet Julierpass, Val Suvretta und Corvatsch (Oberengadin, GR), sowie Versuche zur Relativdatierung der morphologischen Formen mit der Schmidthammer-Methode. Diploma thesis. University of Zürich, Zürich

Casty C, Wanner H, Luterbacher J, Esper J, Böhm R (2005) Temperature and precipitation variability in the European Alps since 1500. Int J Climatol 25:1855-1880

Cleveland WS, Devlin SJ (1988) Locally weighted regression - an approach to regression-analysis by local fitting. J Am Stat Assoc 83:596-610

Douglas MSV, Smol JP (1999) Freshwater diatoms as indicators of environmental change in the High Arctic. In: Stoermer EF, Smol JP (eds) The diatoms: application for the environmental and earth sciences. Cambridge University Press, Cambridge, pp 227-244

Ellenberg H (1996) Vegetation Mitteleuropas mit den Alpen in ökologischer, dynamischer und historischer Sicht. Ulmer, Stuttgart

Gabathuler M (1999) Physical ecosystem determinants in high mountain lakes, the Jöri Lakes, Switzerland.
Doctoral thesis. Swiss Federal Institute of Technology (ETH), Zürich

Gensler GA (1978) Das Klima von Graubünden. Ein Beitrag zur Regionalklimatologie der Schweiz. Professorial dissertation. University of Zürich, Zürich

Gobet E, Hochuli PA, Ammann B, Tinner W (2004) Vom Urwald zur Kulturlandschaft des Oberengadins. Vegetationsgeschichte der letzten 6200 Jahre. Jahrb Schweiz Ges Ur- Frühgesch 87:255-270

Gobet E, Tinner W, Hochuli PA, van Leeuwen JFN, Ammann B (2003) Middle to Late Holocene vegetation history of the Upper Engadine (Swiss Alps): the role of man and fire. Veg Hist Archaeobot 12:143-163

Gowin F, Zavrel J (1944) Novy Procladius z vysokych Tater. Procladius tatrensis Gow. n. sp. Entomol Listy (Folia Entomol) 7:87-90

Grabherr G, Mucina L (1993) Die Pflanzengesellschaften Österreichs. Teil 2. Gustav Fischer Verlag, Jena

Gray DM, Male DH (1981) Handbook of snow: principles, processes, management and use. Pergamon Press, Toronto

Grimås V, Nilsson NA (1962) Nahrungsfauna und Kanadische Seeforelle in Berner Gebirgsseen. Schweiz Z Hydrol 24:49-75

Guilizzoni P, Marchetto A, Lami A, Cameron NG, Appleby PG, Rose NL, Schnell OA, Belis CA, Giorgis A, Guzzi L (1996) The environmental history of a mountain lake (Lago Paione Superiore, central Alps, Italy) for the last c.100 years: a multidisciplinary, palaeolimnological study. J Paleolimnol 15:245-264

Hausmann S, Lotter AF, van Leeuwen JFN, Ohlendorf C, Lemcke G, Gronlund E, Sturm M (2002) Interactions of climate and land use documented in the varved sediments of Seebergsee in the Swiss Alps. Holocene 12:279-289

Heiri O (2001) Holocene palaeolimnology of Swiss mountain lakes reconstructed using subfossil chironomid remains: past climate and prehistoric human impact on lake ecosystems. Doctoral thesis. University of Bern, Bern

Heiri O, Lotter AF (2003) 9000 years of chironomid assemblage dynamics in an Alpine lake: long-term trends, sensitivity to disturbance, and resilience of the fauna. J Paleolimnol 30:273-289

Heiri O, Lotter AF (2005) Holocene and Lateglacial summer temperature reconstruction in the Swiss Alps based on fossil assemblages of aquatic organisms: a review. Boreas 34:506-516

Heiri O, Millet L (2005) Reconstruction of Late Glacial summer temperatures from chironomid assemblages in Lac Lautrey (Jura, France). J Quat Sci 20:33-44

Heiri O, Ekrem T, Willassen E (2004a) Larval head capsules of European Micropsectra, Paratanytarsus and Tanytarsus (Diptera: Chironomidae: Tanytarsini). Version 1.0. http://www.bio.uu.nl/ palaeo/Chironomids/Tanytarsini/intro.htm

Heiri O, Tinner W, Lotter AF (2004b) Evidence for cooler European summers during periods of changing meltwater flux to the North Atlantic. Proc Natl Acad Sci USA 101:15285-15288 
Heiri O, Lotter AF, Hausmann S, Kienast F (2003a) A chironomid-based Holocene summer air temperature reconstruction from the Swiss Alps. Holocene 13:477-484

Heiri O, Wick L, van Leeuwen JFN, van der Knaap WO, Lotter AF (2003b) Holocene tree immigration and the chironomid fauna of a small Swiss subalpine lake (Hinterburgsee, $1515 \mathrm{~m}$ asl). Palaeogeogr Palaeoclimatol Palaeoecol 189:35-53

Juggins S (2003) C2 v.1.4. http://www.campus.ncl.ac.uk/ staff/Stephen.Juggins/software/C2Home.htm

Kamenik C, Schmidt R (2005) Chrysophyte resting stages: a tool for reconstructing winter/spring climate from Alpine lake sediments. Boreas 34:477-489

Karst-Riddoch TL, Pisaric MFJ, Smol JP (2005) Diatom responses to 20th century climate-related environmental changes in high-elevation mountain lakes of the northern Canadian Cordillera. J Paleolimnol 33:265-282

Klucker A (1992) Seen-Bericht. Amt für Jagd und Fischerei Graubünden, Chur

Koch R (2003) Geomorphologische Kartierung im Berninagebiet sowie GIS-basierte Darstellung und Analyse der Geomorphologie im Gebiet Oberengadin (GR). Diploma thesis. University of Zürich, Zürich

Koinig KA, Kamenik C, Schmidt R, Agusti-Panareda A, Appleby PG, Lami A, Prazakova M, Rose N, Schnell OA, Tessadri R, Thompson R, Psenner R (2002) Environmental changes in an alpine lake (Gossenkollesee, Austria) over the last two centuries - the influence of air temperature on biological parameters. J Paleolimnol 28:147-160

Krammer K, Lange-Bertalot H (1986-1999) Bacillariophyceae. Gustav Fischer Verlag, Stuttgart/Jena

Larocque I, Hall RI (2004) Holocene temperature estimates and chironomid community composition in the Abisko Valley, northern Sweden. Quat Sci Rev 23:2453-2465

Larocque I, Hall RI, Grahn E (2001) Chironomids as indicators of climate change: a 100-lake training set from a subarctic region of northern Sweden (Lapland). J Paleolimnol 26:307-322

Leemann A, Niessen F (1994) Holocene glacial activity and climatic variations in the Swiss Alps: reconstructing a continuous record from proglacial lake sediments. Holocene 4:259-268

Livingstone DM (1997) Break-up dates of Alpine lakes as proxy data for local and regional mean surface air temperatures. Clim Change 37:407-439

Lotter AF (2001) The palaeolimnology of Soppensee (Central Switzerland), as evidenced by diatom, pollen, and fossil-pigment analyses. J Paleolimnol 25:65-79

Lotter AF, Bigler C (2000) Do diatoms in the Swiss Alps reflect the length of ice-cover? Aquat Sci 62:125-141

Lotter AF, Birks HJB (2003) The Holocene palaeolimnology of Sagistalsee and its environmental history - a synthesis. J Paleolimnol 30:333-342

Lotter AF, Pienitz R, Schmidt R (1999) Diatoms as indicators of environmental change near Arctic and Alpine treeline. In: Stroemer EF, Smol JP (eds) The diatoms: application to the environmental and earth sciences. Cambridge University Press, Cambridge, pp 205-226

Lotter AF, Birks HJB, Hofmann W, Marchetto A (1997) Modern diatom, cladocera, chironomid, and chrysophyte cyst assemblages as quantitative indicators for the reconstruction of past environmental conditions in the Alps. I. Climate. J Paleolimnol 18:395-420

Lotter AF, Birks HJB, Hofmann W, Marchetto A (1998) Modern diatom, cladocera, chironomid, and chrysophyte cyst assemblages as quantitative indicators for the reconstruction of past environmental conditions in the Alps. II. Nutrients. J Paleolimnol 19:443-463

Lotter AF, Birks HJB, Eicher U, Hofmann W, Schwander J, Wick L (2000) Younger Dryas and Allerød summer temperatures at Gerzensee (Switzerland) inferred from fossil pollen and cladoceran assemblages. Palaeogeogr Palaeoclimatol Palaeoecol 159:349-361

Lotter AF, Appleby PG, Bindler R, Dearing JA, Grytnes JA, Hofmann W, Kamenik C, Lami A, Livingstone DM, Ohlendorf C, Rose N, Sturm M (2002) The sediment record of the past 200 years in a Swiss highalpine lake: Hagelseewli (2339 ma.s.1.). J Paleolimnol 28:111-127

Maisch M, Burga CA, Fitze P (1999) Lebendiges Gletschervorfeld. Führer und Begleitbuch zum Gletscherlehrpfad Morteratsch. University of Zürich, Zürich

Maisch M, Wipf A, Denneler J, Battaglia J, Benz C (2000) Die Gletscher der Schweizer Alpen. vdf Hochschulverlag, Zürich

Margreth S (2006) Partikelfluss und Sedimentbildung in Oberengadiner Seen. MSc thesis. University of Zürich, Zürich

Marrer H (1975) Notiz über die fischereiliche Begehung des Lej da la Tscheppa vom 29. August 1975. Amt für Jagd und Fischerei Graubünden, Chur

Moore PD, Webb JA, Collinson ME (1991) Pollen analysis. Blackwell Scientific Publications, Oxford

Müller B, Lotter AF, Sturm M, Ammann A (1998) Influence of catchment quality and altitude on the water and sediment composition of 68 small lakes in Central Europe. Aquat Sci 60:316-337

Ohlendorf C (1998) High Alpine lake sediments as chronicles for regional glacier and climate history in the Upper Engadine, southeastern Switzerland. Ph. D. thesis No. 12705. ETH, Zürich

Ohlendorf C, Niessen F, Weissert H (1997) Glacial varve thickness and 127 years of instrumental climate data: a comparison. Clim Change 36:391-411

Pechlaner R (1966) Salmonideneinsätze in Hochgebirgsseen und -tümpel der Ostalpen. Verh Int Ver Limnol 16:1182-1191

Pechlaner R (1984) Historical evidence for the introduction of Arctic charr into high-mountain lakes of the Alps by man. In: Johnson L, Burns BL (eds) Biology of the Arctic Charr, proceedings of the international symposium on Arctic charr, Winnipeg, Manitoba, May 1981. University of Manitoba Press, Winnipeg, pp 549-557

Porinchu DF, MacDonald GM, Bloom AM, Moser KA (2002) The modern distribution of chironomid 
sub-fossils (Insecta: Diptera) in the Sierra Nevada, California: potential for paleoclimatic reconstructions. J Paleolimnol 28:355-375

Punt W, Clarke GCS (1984) The northwest European pollen flora, Parts 29-37. Elsevier Science Publishers, Amsterdam

Punt W, Blackmore S, Hoen PP (1995) The Nortwest European Pollen Flora, Parts 52-56. Elsevier Science Publishers, Amsterdam

Reisigl H, Keller R (1987) Alpenpflanzen im Lebensraum. Alpine Rasen, Schutt- und Felsvegetation. Gustav Fischer Verlag, Stuttgart

Rieradevall M, Brooks SJ (2001) An identification guide to subfossil Tanypodinae larvae (Insecta: Diptera: Chironomidae) based on cephalic setation. J Paleolimnol 25:81-99

Rose N (2001) Fly-ash particles. In: Last WM, Smol JP (eds) Physical and geochemical methods. Kluwer Academic Publishers, Dordrecht, The Netherlands, pp 319-349

Rüdishühli M (2001) Raumentwicklung Oberengadin. Diploma thesis. University of Applied Sciences Rapperswil, Rapperswil, Switzerland

Schmid PE (1993) A key to the larval Chironomidae and their instars from Austrian Danube region streams and rivers with particular reference to a numerical taxonomic approach. Part I. Diamesinae, Prodiamesinae and Orthocladiinae. Wasser Abwasser Suppl 3:1-514

Schmidt R, Kamenik C, Kaiblinger C, Hetzel M (2004a) Tracking Holocene environmental changes in an alpine lake sediment core: application of regional diatom calibration, geochemistry, and pollen. J Paleolimnol 32:177-196

Schmidt R, Kamenik C, Lange-Bertalot H, Klee R (2004b) Fragilaria and Staurosira (Bacillariophyceae) from sediment surfaces of 40 lakes in the Austrian Alps in relation to environmental variables, and their potential for palaeoclimatology. J Limnol 63:171-189

Serra-Tosio B (1978) Les Diptères chironomidés du Lac de Mont Coua (Parc National de la Vanoise). Trav Sci P Natl Vanoise 9:141-145

Smol JP (1988) Paleoclimate proxy from freshwater arctic diatoms. Verh Int Ver Limnol 23:837-844

Sorvari S, Korhola A, Thompson R (2002) Lake diatom response to recent Arctic warming in Finnish Lapland. Glob Change Biol 8:171-181
Stockmarr J (1971) Tablets with spores used in absolute pollen analysis. Pollen Spores 13:615-621

Swiss Federal Institute for Snow and Avalanche Research (2004) SLF database. Swiss Federal Institute for Snow and Avalanche Research, Davos

Swiss Federal Office of Energy (2004) Energy consumption in Switzerland 2004. Overall energy statistics 2004. BBL, Vertrieb Publikationen, Bern

ter Braak CJF, Juggins S (1993) Weighted averaging partial least-squares regression (Wa-Pls) - An improved method for reconstructing environmental variables from species assemblages. Hydrobiologia 269:485-502

ter Braak CJF, Juggins S, Birks HJB, van der Voet H (1993) Weighted-averaging-partial least square regression (WA-PLS): definition and comparison with other methods for species-environmental calibration. In: Patil GP, Rao CR (eds) Multivariate environmental statistics. Elsevier Science Publishers, Amsterdam, pp 525-560

Tinner W, Kaltenrieder P (2005) Rapid responses of highmountain vegetation to early Holocene environmental changes in the Swiss Alps. J Ecol 93:936-947

Tinner W, Lotter AF, Ammann B, Conedera M, Hubschmid P, van Leeuwen JFN, Wehrli M (2003) Climatic change and contemporaneous land-use phases north and south of the Alps $2300 \mathrm{BC}$ to $800 \mathrm{AD}$. Quat Sci Rev 22:1447-1460

Wick L, van Leeuwen JFN, van der Knaap WO, Lotter AF (2003) Holocene vegetation development in the catchment of Sagistalsee (1935 m asl), a small lake in the Swiss Alps. J Paleolimnol 30:261-272

Wiederholm T (1983) Chironomidae of the Holarctic region. Keys and diagnoses. Part I. Larvae. Entomol Scand Suppl 19:1-457

Woodward CA, Shulmeister J (2006) New Zealand chironomids as proxies for human-induced and natural environmental change: transfer functions for temperature and lake production (chlorophyll a). J Paleolimnol 36:407-429

Zoller H, Brombacher C (1984) Das Pollenprofil "Chalavus" bei St. Moritz - Ein Beitrag zur Wald- und Landwirtschaftsgeschichte im Oberengadin. Diss Bot 72:377-398

Züllig H (1982) Untersuchungen über die Stratigraphie von Carotinoiden im geschichteten Sediment von 10 Schweizer Seen zur Erkundung früherer Phytoplankton-Entfaltungen. Schweiz Z Hydrol: 1-98 